Andreas Bick

\title{
A new Spionidae (Polychaeta) from North Carolina, and a redescription of Marenzelleria wireni Augener, 1913, from Spitsbergen, with a key for all species of Marenzelleria
}

Received: 5 October 2004/ Revised: 1 April 2005Accepted: 7 June 2005 / Published online: 29 September 2005

(C) Springer-Verlag and AWI 2005

\begin{abstract}
Marenzelleria bastropi, a new species of Spionidae (Polychaeta) from the brackish water Currituck Sound, North Carolina, is described. The new species is characterized by the great number of chaetigers between the first neuro- and notopodial hooded hooks, the extension of the nuchal organ up to the end of chaetiger 2 /middle of chaetiger 3 and the presence of about $60-90$ branchiate chaetigers. Marenzelleria bastropi sp. nov. is closely related to M. neglecta (Sikorski and Bick, 2004) and Marenzelleria viridis (Verrill, 1873). Marenzelleria wireni Augener, 1913 is described here for the first time from western Spitsbergen. Adult specimens are investigated and compared with specimens from other areas of distribution. A key for subadult and adult specimens of all Marenzelleria species is provided.
\end{abstract}

Keywords Marenzelleria bastropi sp. nov. · Currituck Sound - Marenzelleria wireni - Spitsbergen

\section{Introduction}

During studies on the identity and distribution of Marenzelleria species in European and North American brackish waters specimens were found in Currituck Sound, North Carolina, that could not be assigned to any known species. These specimens were discovered independently of one another through genetic and morphological investigations. Besides the two genetic types (Type I and Type II) that were later determined as Marenzelleria $\mathrm{cf}$. wireni and $M$. cf. viridis, a third genetic type (Type III) was restricted to Currituck Sound; it was

Communicated by R.M. Kristensen

A. Bick $(\bowtie)$

FB Biowissenschaften, Universität Rostock,

Allgemeine and Spezielle Zoologie Universitätsplatz 2,

18051 Rostock, Germany

E-mail: andreas.bick@biologie.uni-rostock.de

Tel.: + 49-381-4986267

Fax: + 49-381-4986262 sympatric with Type II (37 specimens of Type III and 72 of Type II) (Bastrop et al. 1997). Morphological investigations yielded one anterior fragment (Marenzelleria sp. A) which also markedly differed from species known from boreal regions (Bick and Zettler 1997). Specimens recently collected from the Currituck Sound now make a formal description of this species possible, although only anterior fragments are available again.

Moreover, several specimens of $M$. wireni were recently collected from a glacier fjord in western Spitsbergen. It represents the third record of $M$. wireni from Svalbard and the first from the west coast of Spitsbergen. For the first time, several complete adult specimens rather than a single specimen or anterior fragments are available. These specimens will help during morphological and genetic investigations as part of a preliminary study for phylogenetic and phylogeographic analyses of all Marenzelleria species. The results of the morphological investigations on $M$. wireni are provided in this paper, and the analyses will be presented in a later contribution. A key to all species of Marenzelleria is also provided.

\section{Methods}

The specimens of Marenzelleria bastropi sp. nov. were collected in intertidal areas in Currituck Sound, North Carolina, in June 1995 and October 2002. The salinity at the sampling locality was about 4 psu (June 1995) but the sediment character is unknown. The samples were fixed in borax-buffered formalin (1995) or ethanol (2002). The specimens of $M$. wireni were collected in intertidal and shallow subtidal areas of the Kolhamna Bukta, Kongsfjorden, near Ny Ålesund, Spitsbergen, in June 2003. Here, oceanic water of 29.8 psu was overlain by brackish water of $4.6 \mathrm{psu}$. The sediment consisted of fine well-sorted sand with a relatively small amount of organic matter. Before specimens were fixed with a $4 \%$ buffered formalin solution they were anaesthetized by carefully adding carbonated fresh-water. For SEM 
studies, specimens were dehydrated in a critical point drier, attached to a stub and sputter-coated with gold palladium. SEM observations were made with a Zeiss DSM 960 A. Methylene green staining was employed to visualise the extension of the nuchal organ and glandular body regions. All specimens examined in the present study are deposited in the Zoologische Sammlung der Universität Rostock (ZSRO); catalogue numbers see below.

\section{Results}

Spionidae Grube, 1850

Marenzelleria Mesnil, 1896

Type species: M. wireni Augener, 1913

Marenzelleria bastropi sp. nov.

Synonymy: Marenzelleria sp. A-Bick and Zettler (1997): 143, Sikorski and Bick (2004): 271, Fig. 8; Marenzelleria Type III-Bastrop et al. 1997: 126-127, 1998: 99-100.

Material examined: Holotype: Currituck Sound, North Carolina, Waterlilly, 31.10.2002, coll. D.M. Dauer, (ZSRO-P1637). Paratypes: Currituck Sound, North Carolina, Waterlilly, 31.10.2002, coll. D.M. Dauer, (one specimen, ZSRO-P1638); Currituck Sound, North Carolina, eulittoral, salinity 4 psu, June 1995, coll. R. Bastrop (one specimen, ZSRO-P 45); Nontype material: Currituck Sound, North Carolina, Waterlilly, 31.10.2002, coll. D.M. Dauer, three specimens (used for both scanning electron microscope and genetic analyses).

\section{Diagnosis}

Holotype: anterior fragment with 85 chaetigers; maximum width about $2.1 \mathrm{~mm}$; body somewhat flattened; anterior margin of prostomium broadly rounded, notched medially; prostomium bell shaped; eyes not visible; palps broken off; nuchal organ up to the end of chaetiger 2; midsegmental and intersegmental dorsal ciliated crest present from chaetiger 2 and between chaetiger 2 and 3 (Figs. 1a, d, 2a); branchiae from chaetiger 1 up to chaetiger 77 , branchiae on the first chaetigers distinctly longer than postsetal lamellae of the notopodium, touch dorsally on chaetigers 1-3 (Fig. 1b, 2b, c); branchiae increase in length up to chaetiger 6 , of equal length from chaetiger 6 up to about chaetiger 35 , and decrease markedly in length on most posterior chaetigers; postsetal lamellae present on all chaetigers, inconspicuous on most posterior chaetigers; postsetal notopodial lamellae and branchiae fused basally, on first ten chaetigers pointed dorsally, after that rounded (Fig. 1b, c), about twice as long as wide anteriorly, square or rounded posteriorly; postsetal neuropodial lamellae much smaller than notopodial lamellae, rounded in all but posteriormost chaetigers; all chaetigers with capillary chaetae, supe- rior dorsal chaetae longest, most striking on chaetigers 1-3, where they raised dorsally; ventrally curved tapering sabre chaetae start from neuropodium 4, with one to three in each fascicle; hooded hooks are present in neuro- and notopodium, neuropodial hooks first appear on chaetiger 44, notopodial hooks start on chaetiger 67; hooks are bidentate with a small tooth above the main tooth, sometimes small tooth reduced or doubled (Fig. 1e, f, 2 d); no distinct methylene green staining pattern.

\section{Remarks}

The characters of the investigated specimens are presented in Table 1. Marenzelleria bastropi sp. nov is characterized by the great number of chaetigers (23-28) between the first neuropodial and the first notopodial hooded hooks. All other known species of Marenzelleria have about 10-12 (maximum 15) chaetigers between the first neuropodial and the first notopodial hooks. Moreover, no other adult specimens of Marenzelleria show the following combination of characters, nuchal organ extending up to the end of chaetiger $2 /$ middle of chaetiger 3 (Fig. 1a), and up to 90 branchiate chaetigers. The most closely related species are M. neglecta Sikorski and Bick, 2004 and $M$. viridis (Verrill, 1873). Subadult specimens of $M$. neglecta have a nuchal organ of similar length (Fig. 3c), but they have fewer branchiate chaetigers (Table 1). Marenzelleria viridis possesses a similar number of branchiate chaetigers, but the nuchal organ does not cross the midsegmental ciliated crest on chaetiger 2 (Fig. 3d). Consideration has been given to the fact that all diagnostic characters (length of nuchal organ, number of branchiate chaetigers, first appearance of neuro- and notopodial hooded hooks) of Marenzelleria species are size-dependent (Bick and Zettler 1997; Sikorski and Bick 2004). Moreover, identification is not only based on the combination of characters but also on the inclusion of 'secondary characters' (arithmetical differences between morphological characters) (Sikorski and Bick 2004).

Among the investigated material, one specimen (without catalogue number*) differed remarkably from the others (Table 1): the number of chaetigers between first appearance of noto- and neuropodial hooded hooks is 12 . This number agrees with those found in the other Marenzelleria species. The two other important characters found on this specimen-length of nuchal organ and number of branchiate chaetigers - is certainly unique among Marenzelleria species. Genetic analysis detected a correspondence between this specimen and all others of M. bastropi sp. nov. (M. Blank, personal communication) but this phenomenon remains unclear. One potential explanation is hybridisation, such as the one known to occur between $M$. neglecta (=Type II) and $M$. viridis (=Type I): $\mathrm{F}_{1}$-hybrids have been found in the Elbe estuary (Blank et al. 2004). 

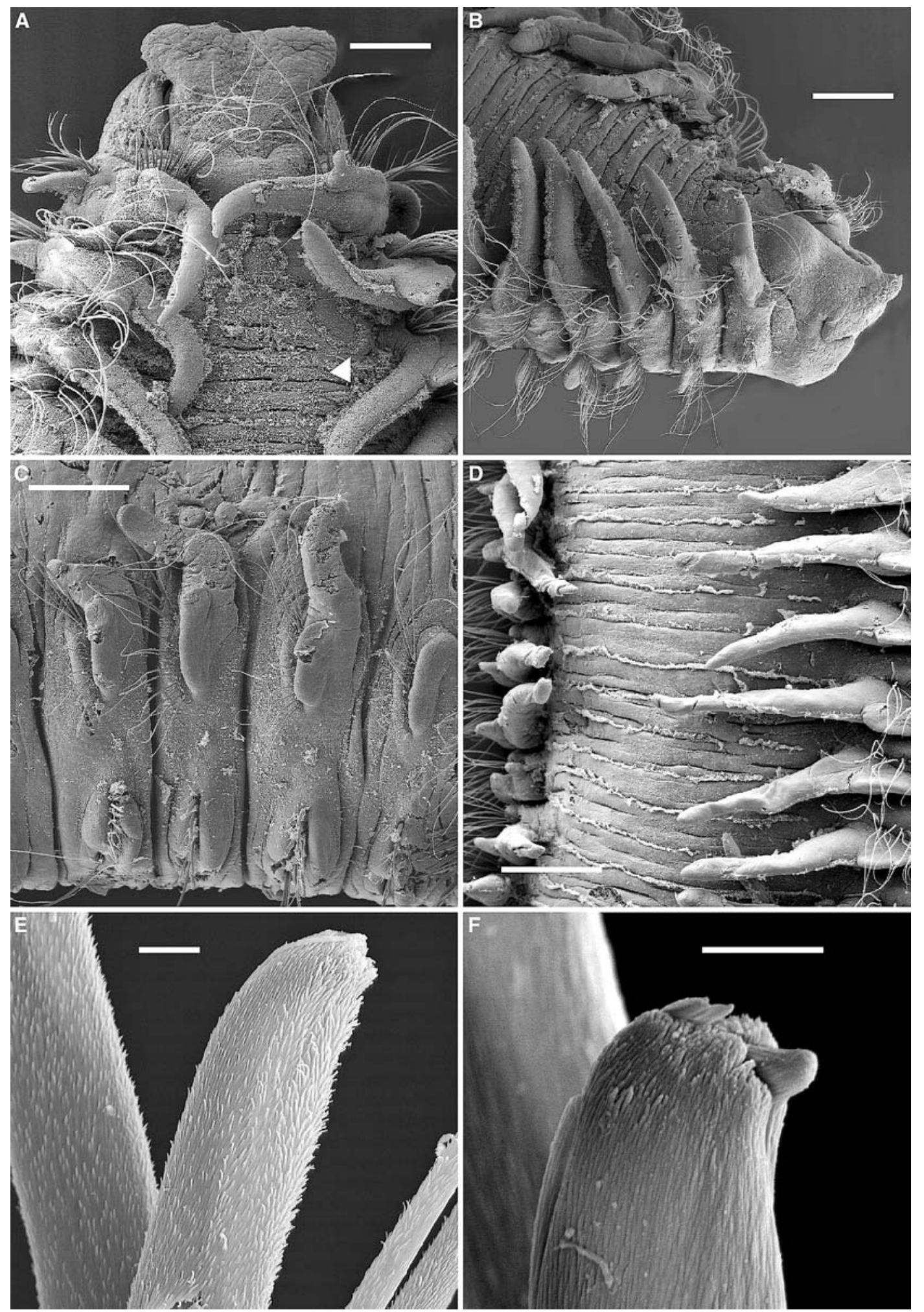

Fig. 1 Marenzelleria bastropi sp. nov. a Anterior end, dorsal view (arrowhead indicates the posterior margin of the right loop of the nuchal organ). b Anterior end, lateral view. $\mathbf{c}$ Branchiate chaetigers, lateral view. d Branchiate region, dorsal view with mid- and

Such a hybridisation is conceivable between M. bastropi sp. nov. and $M$. neglecta, which occur sympatrically in Currituck Sound.

intersegmental ciliated crests. e Neuropodial hooded hook, hood closed apically. F Tridentate neuropodial hooded hook, hood open; (scale in a-d $200 \mu \mathrm{m}, \mathbf{e}, \mathbf{f} 5 \mu \mathrm{m}$ )

Marenzelleria bastropi sp. nov is only known from the type locality. It was found together with $M$. neglecta at about 4 psu. The ratio of abundance between $M$. neg- 
A

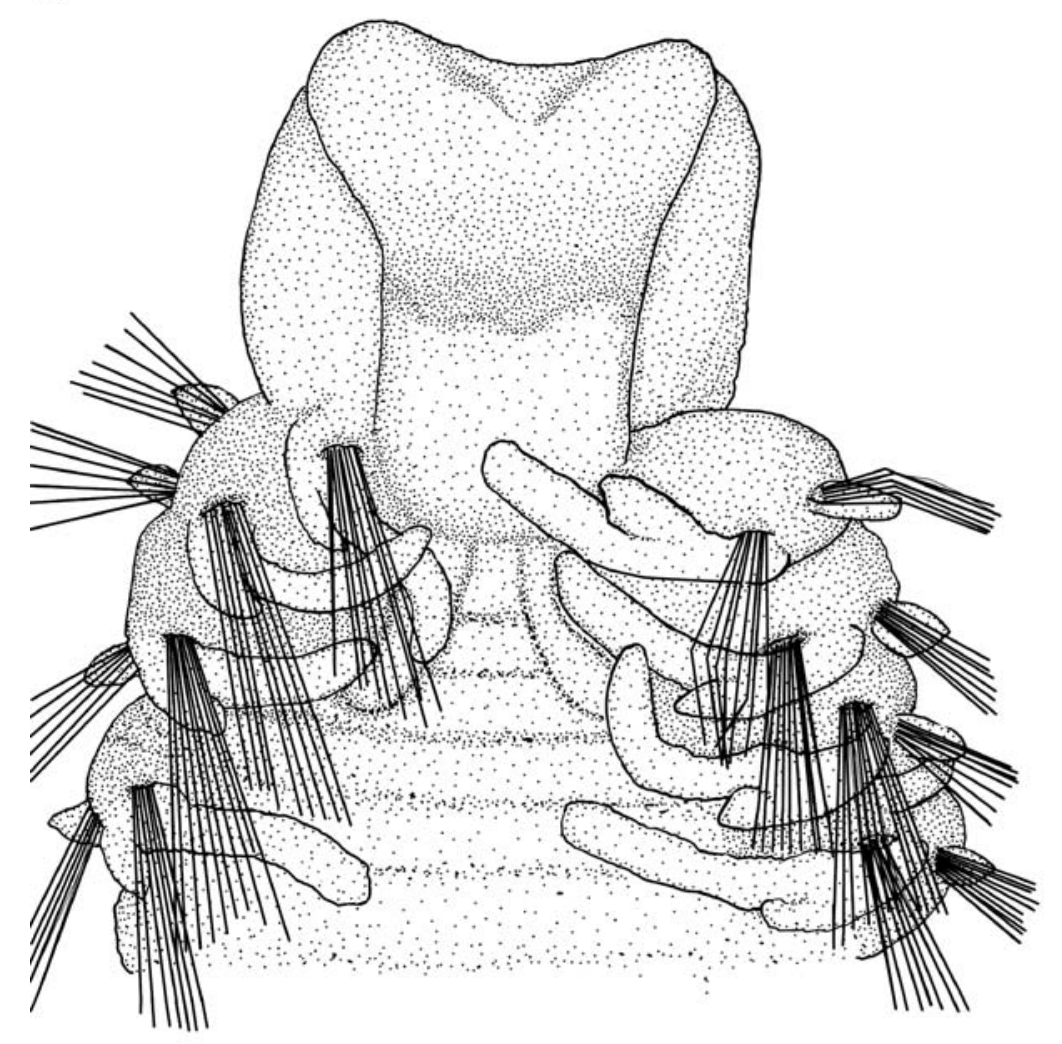

D

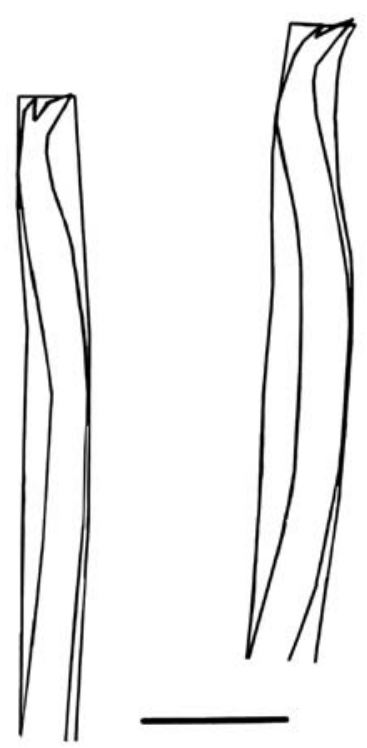

B
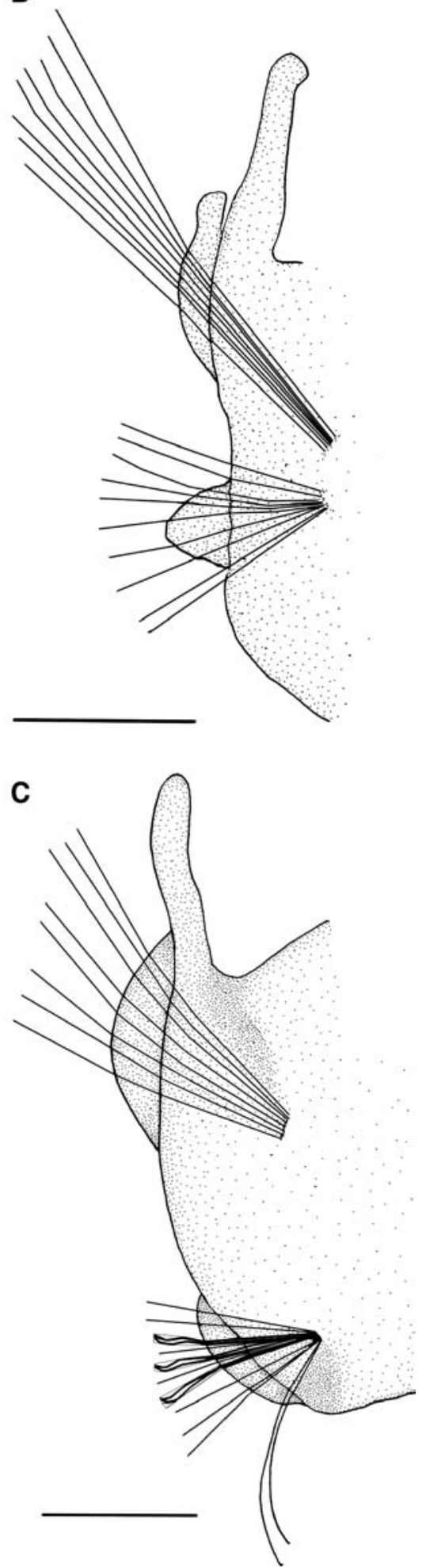

Fig. 2 Marenzelleria bastropi sp. nov. a Anterior end, dorsal view. b Chaetiger 3, anterior view. c Chaetiger 45, anterior view. d Neuropodial hooded hooks; (scale in a $1 \mathrm{~mm}, \mathbf{b}$, c $200 \mu \mathrm{m}, \mathbf{d} 20 \mu \mathrm{m}$ )

lecta and M. bastropi was about 2:1 in June 1995 and about 30:1 in October 2002. An explanation for this will have to wait until more is known about the ecology and true distribution of $M$. bastropi sp. nov.
Etymology: The species is named after Dr Ralf Bastrop, University of Rostock, to honour him for his contribution to the population genetics of Marenzelleria spp. He was the first person to find 'Marenzelleria Type III'. 


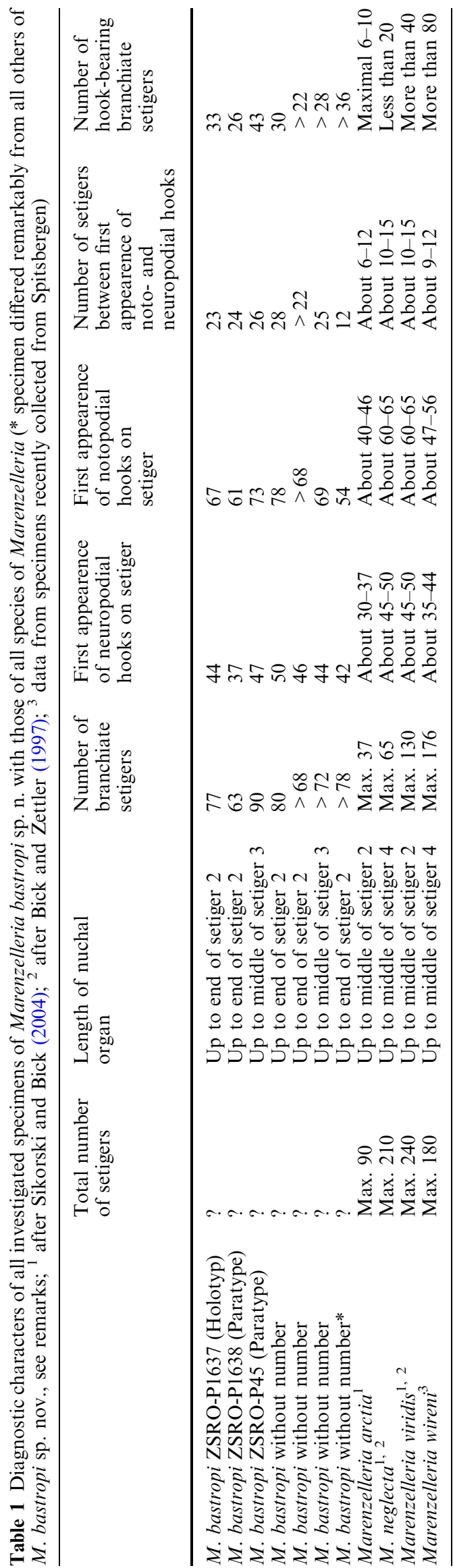

Marenzelleria wireni Augener, 1913

Synonymy: Marenzelleria wireni Augener, 1913: 264 267, Figs. 1, 2 (partim); Annenkova 1952: 126; Maciolek 1984: 49-51, Figs. 1a-g (partim); Sikorski et al. 1988: 835-837, Fig. 4 (partim); Sikorski and Buzhinskaya 1998: 1112-1115, Fig. 1; Sikorski and Bick 2004: 255261, Figs. 1, 2a; non Holmquist 1967: 298-313; non Marenzelleria cf. wireni, Bick and Zettler 1997: 138-141, Figs. 1, 2. Marenzelleria arctia, Sikorski and Buzhinskaya 1998 (partim): 1115-1118. Spio gorbunovi Averintsev, 1990: 165-166, Fig. 13. Nerine vulgaris Wirén, 1883: 408 (partim). Scolecolepis sp. Marenzeller, 1892: 427-429, Fig. 5. Microspio wireni Söderström, 1920: 249-250 (partim).

Material examined: Spitsbergen, Kongsfjorden, Kolhamna Bukta near Ny Alesund, eulittoral, fine sand, 18.06.2003, eight specimens (ZSRO-P1634); Spitsbergen, Kongsfjorden, Kolhamna Bukta near Ny Alesund, eulittoral, fine sand, 17.06.2003, three specimens (ZSRO-P1635); Spitsbergen, Kongsfjorden, Kolhamna Bukta near Ny Ålesund, eulittoral, fine sand, 19.06.2003, seven specimens (ZSRO-P1636).

\section{Diagnosis}

Specimens 40-72 mm long and 106-180 chaetigers; maximum width about $2 \mathrm{~mm}$; body rounded anteriorly and somewhat flattened posteriorly; anterior margin of prostomium broadly rounded, with a small notch medially; prostomium bell shaped; four eyes trapeziformly arranged with posterior pair more closely spaced and dorsally orientated and anterior pair laterally orientated; palps broken off; nuchal organ from posterior margin of prostomium up to middle of chaetiger 3 to the beginning of chaetiger 4 (Fig. 3a); midsegmental and intersegmental dorsal ciliated crest present from chaetiger 2 and chaetiger 2 and 3; first chaetigers with a large number of dorsally located pores (Fig. 3b); branchiae from chaetiger 1 up to chaetigers 88-176, i.e. branchiae are absent only in the very last chaetigers; branchiae in the first chaetigers are distinctly longer than postsetal lamellae of the notopodium and may touch dorsally from chaetiger 1 up to about chaetiger 30; branchiae increase in length up to chaetigers 10-15, then of equal length up to two-thirds of the total number of chaetigers, and decrease markedly in length only in the most posterior chaetigers, triangular anteriorly and threadlike on middle and posterior chaetigers; postsetal lamellae on all chaetigers; postsetal notopodial lamellae and branchiae almost completely fused, distally rounded, about twice as long as wide anteriorly, rounded posteriorly; postsetal neuropodial lamellae much smaller than notopodial lamellae, rounded in all but posteriormost chaetigers; all chaetigers with capillary chaetae, superior dorsal chaetae longest, most striking on anteriormost chaetigers; ventrally curved and tapering sabre chaetae start from neuropodium 4, with three to five in each fascicle; hooded hooks are present in neuro- and noto- 

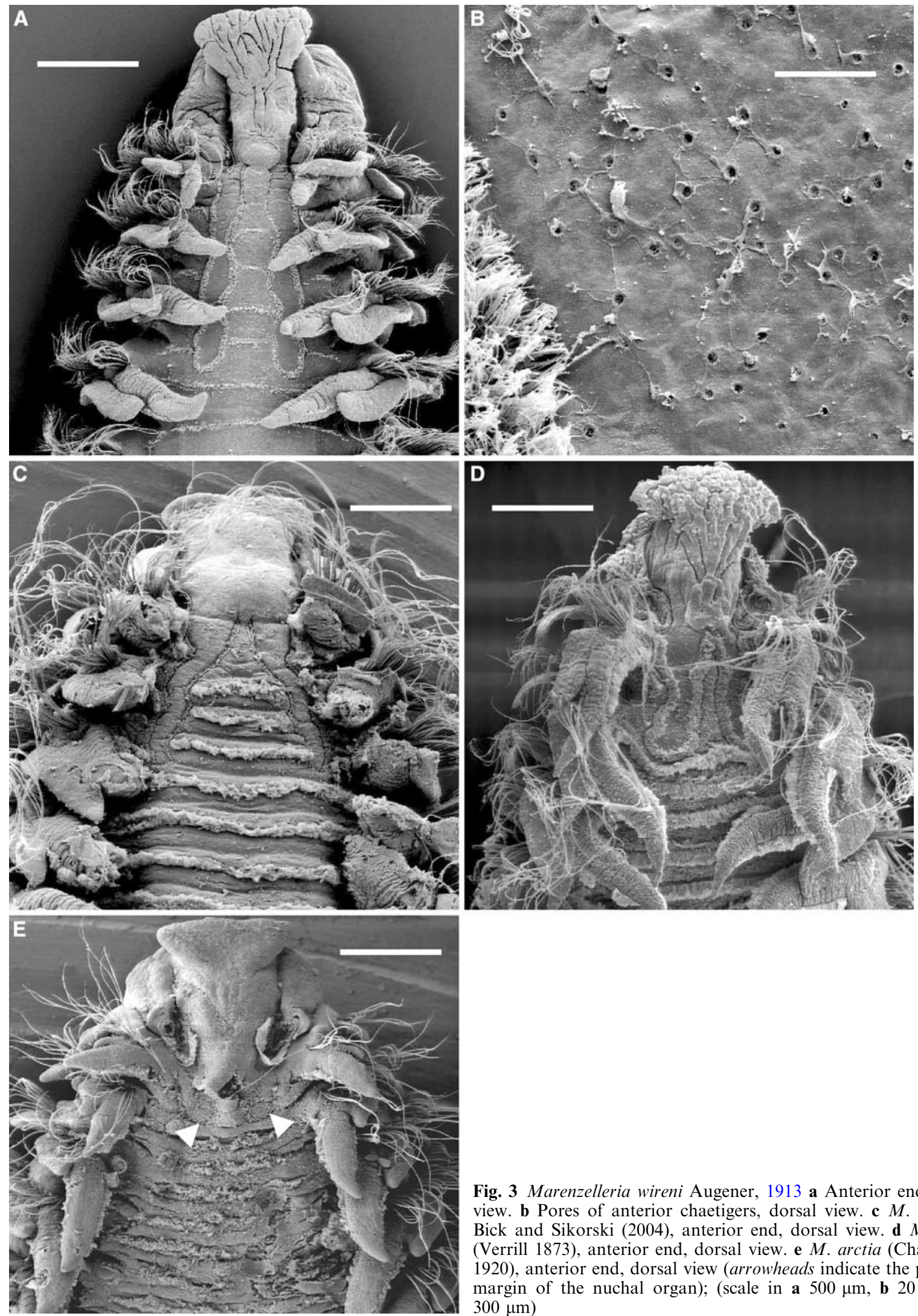

Fig. 3 Marenzelleria wireni Augener, 1913 a Anterior end, dorsal view. b Pores of anterior chaetigers, dorsal view. c $M$. neglecta, Bick and Sikorski (2004), anterior end, dorsal view. d M. viridis (Verrill 1873), anterior end, dorsal view. e M. arctia (Chamberlin 1920), anterior end, dorsal view (arrowheads indicate the posterior margin of the nuchal organ); (scale in a $500 \mu \mathrm{m}$, b $20 \mu \mathrm{m}$, c-e $300 \mu \mathrm{m})$

podia, neuropodial hooks first appear on chaetigers 35 44 , notopodial hooks usually start on chaetigers $47-56$; hooks are bi- or tridentate; slit-like anus surrounded by anal papillae and up to 14 filamentous anal cirri, sometimes branched dichotomously; no distinct methylene green staining pattern. 
Remarks

Specimens from Spitsbergen largely agree with those examined by Sikorski and Bick (2004) from other Arctic regions. Marenzelleria wireni is clearly characterized by the great number of branchiate chaetigers (Table 1), and the length of the nuchal organ. Only in M. neglecta and $M$. wireni does the nuchal organ reach or cross the intersegmental ciliated crest between chaetigers 3 and 4 (Fig. 3a, c). The nuchal organ of the other known Arctic species, M. arctia, never crosses the midsegmental ciliated crest of chaetiger 2 (Fig. 3e). The many dorsal pores on the first chaetigers of the Spitsbergen specimens (Fig. 3b) have also been found on a specimen from the White Sea (ZISP 49488) but not on other species of Marenzelleria. This may be considered a useful diagnostic character of $M$. wireni.

Marenzelleria wireni has mainly been found in finesand brackish habitats of shallow subtidal and upper intertidal areas in the Kongsfjorden near Ny Alesund, western Spitsbergen, in a benthic community dominated by the polychaetes Euchone analis (Krøyer, 1856) and Pygospio elegans Claparède, 1863. The maximum abundance was 250 ind. $\mathrm{m}^{-2}$. It has also been found in subtidal areas (5 and $10 \mathrm{~m}$ depth) at an abundance of about 10 ind. $\mathrm{m}^{-2}$ (Herrmann 2004). Juveniles have not been found, and all specimens collected in this area belong to one size class. Juveniles and adults may prefer different substrates, as is known for M. neglecta (Zettler 1996). Remarkably, M. wireni has only been found twice before from Spitsbergen, once at Whales-Point Bay, eastern Spitsbergen (Marenzeller 1892, material probably lost), and once at Haketangen, Storfjorden, southeast Spitsbergen (ZMUC-POL 1007). Both were found at a depth of 5$10 \mathrm{~m}$. The former was an anterior fragment, $41 \mathrm{~mm}$ long, $2.75 \mathrm{~mm}$ wide (with or without parapodia?) and possessing 148 chaetigers, the latter was a juvenile specimen with a length of $17 \mathrm{~mm}$ and 96 chaetigers. It is possible that the sampling methods used by us and by SCUBA-divers (Herrmann 2004) - a tube corer and an airlift system, respectively, each sampling the uppermost $20 \mathrm{~cm}$-are more efficient for this tubedwelling polychaete.

\section{Key for Marenzelleria species}

The following key is based on the characteristics of subadult and adult specimens (e.g. width about $>1.2 \mathrm{~mm}$ ). Methylene green staining may be helpful to see the nuchal organ. Additional characters for species are provided in parentheses.
1 Branchiae on all chaetigers except on the very last; nuchal organ at least up to the end of chaetiger $3 /$ beginning of chaetiger 4 , i.e. crossing the intersegmental ciliated crest of chaetigers 3/4 (Fig. 3A); (up to 180 chaetigers; Arctic species).....M. wireni Augener, 1913 Two third of all chaetigers with branchiae at most; nuchal organ up to end of chaetiger 2 or

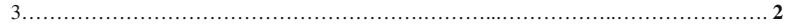

2 More than 20 chaetigers between first appearance of neuro- and notopodial hooded hooks; (nuchal organ from end of chaetiger 2 to middle of chaetiger 3, i.e. reaching the intersegmental ciliated crest of chaetigers $2 / 3$ at least (Fig. 1A); more than 60 branchiate chaetigers; boreal species) ........................................... bastropi sp. nov. - Maximum of 15 chaetigers between first appearance of neuro- and notopodial hooded hooks.

3 Nuchal organ up to the end of chaetiger 3, i.e. crossing the intersegmental ciliated crest of chaetiger 2/3 at least (Fig. 3C); (max. 65 branchiate chaetigers, i.e. less than one-third of tota number of chaetigers; length of branchiae decreases over about 10-15 chaetigers, after that branchiae absent; up to 210 chaetigers; boreal and (Arctic?) species) M. neglecta Sikorski and Bick, 2004

- Nuchal organ much shorter, not crossing the midsegmental ciliated crest of chaetiger 2 .

4 About 30-40 branchiate chaetigers; length of branchiae decreases over about 10-15 chaetigers, after that branchiae absent; (nuchal organ reaches the midsegmental ciliated crest of chaetiger 2 (Fig. 3E); less than 100 chaetigers; Arctic species)

.M. arctia (Chamberlin, 1920)

- About 60-130 branchiate chaetigers, length of branchiae decreases over about 30-60 chaetigers; (nuchal organ reaches the midsegmental ciliated crest of chaetiger 2 (Fig. 3D); 170-240

chaetigers, boreal species).................................... virdis (Verrill, 1873)

Acknowledgements I am grateful to Daniel Dauer for collecting Marenzelleria specimens from Currituck Sound. Collecting of $M$. wireni was supported by a grant from the Deutsche Forschungsgemeinschaft (SPP 1158, Antarktisforschung mit vergleichenden Untersuchungen in arktischen Eisgebieten, BI 758/2-1). I am thankful for the support of the Electron Microscopic Centre of the Medical Faculty of the University of Rostock. I am obliged to Dr M. Stachowitsch for scientific English copyediting. I gratefully acknowledge helpful comments on the manuscript by Dr Susan Chambers.

\section{References}

Annenkova NP (1952) Polychaeta of the Chookchee Sea and the Bering Strait. The far north-east of the Union of SSR 2 (in Russian). Acad Sci Press, New York, pp 112-137

Augener H (1913) Polychaeten von Franz-Joseph-Land II. Zool Anz 41:253-273

Averintsev VG (1990) Polychaetous fauna of the Laptev Sea(in Russian). Issled Fauny Morei 37:147-186

Bastrop R, Röhner M, Sturmbauer C, Jürss K (1997) Where did Marenzelleria spp. (Polychaeta: Spionidae) in Europe come from? Aquat Ecol 31:119-136

Bastrop R, Jürss K, Sturmbauer C (1998) Cryptic species in a marine polychaete and their independent introduction from North America to Europe. Mol Biol Evol 15:97-103 
Bick A, Zettler ML (1997) On the identity and distribution of two species of Marenzelleria in Europe and North America. Aquat Ecol 31:137-148

Blank M, Bastrop R, Röhner M, Jürss K (2004) Effect of salinity on spatial distribution and cell volume regulation in two sibling species of Marenzelleria (Polychaeta: Spionidae). Mar Ecol Prog Ser 271:193-205

Herrmann M (2004) Makrozoobenthos-Gemeinschaften arktischer Weichböden: Struktur und Bedeutung als Nahrungsgrundlage demersaler Fische. Diploma thesis, Univ Kiel, $96 \mathrm{p}$

Holmquist C (1967) Marenzelleria wireni Augener-a polychaete found in fresh waters of northern Alaska-with taxonomical considerations on some related spionid worms. Z Zool Syst Evol forsch 5:298-313

Maciolek NJ (1984) New records and species of Marenzelleria Mesnil and Scolecolepides Ehlers (Polychaeta; Spionidae) from Northeastern North America. In: Proceedings of the first international polychaete conference, Sydney, pp 48-62

von Marenzeller E (1892) Zoologische Ergebnisse der im Jahre 1889 auf Kosten der Bremer Geographischen Gesellschaft von Dr. Willy Kükenthal und Dr. Alfred Walter ausgeführten Expedition nach Ostspitzbergen. Polychaeten Zool Jahrb (Abt Syst) 6:397-434
Sikorski AV, Bick A (2004) Revision of Marenzelleria Mesnil, 1896 (Spionidae, Polychaeta). Sarsia 89:1-24

Sikorski AV, Buzhinskaya GN (1997) The genus Marenzelleria (Polychaeta, Spionidae) in seas of Russia(in Russian). Zool Zh 77:1111-1120

Sikorski AV, Jirkov IA, Tzetlin AB (1988) The genus Laonice (Polychaeta, Spionidae) within the Arctic Ocean: weighting the taxonomic characters and species composition(in Russian). Zool Zh 67:826-838

Söderström A (1920) Studien über die Polychaetenfamilie Spionidae. Doctoral thesis Univ Uppsala, 287 p

Wirén A (1883) Chætopoda från Sibirska ishavet och Berings Haf insamlande under Vega-Expeditionen 1878-1879. Vega-Exped Vetensk Arb 2:381-428

Zettler ML (1996) Ökologische Untersuchungen am Neozoon Marenzelleria viridis (Verrill, 1873) (Polychaeta: Spionidae) in einem Küstengewässer der südlichen Ostsee. Doctoral thesis Univ Rostock, 149 p 